\title{
SOCIO-PSYCHOLOGICAL FACTORS AS CORRELATES OF STUDENTS' PERFORMANCE IN CHEMISTRY: IMPLICATION FOR SCIENCE AND ENGINEERING EDUCATION
}

\author{
NGOZI M. EYA ${ }^{1}$, FLORENCE O. ATTAH ${ }^{2}$, IJEOMA, H.N. NWOJI ${ }^{3}$, CHRISTIAN S. UGWUANYI ${ }^{4}$, \\ CHINEDU I.O. OKEKE ${ }^{5}$ \& UCHECHUKWU H. ONAH ${ }^{6}$ \\ ${ }^{1,2,3,4}$ Department of Science Education, Faculty of Education, University of Nigeria, Nsukka
}

${ }^{4}$ Postdoctoral Fellow, School of Education Studies, Faculty of Education, University of the Free State, Bloemfontein, 9300, South Africa

${ }^{5}$ Host, Professor, and Head, School of Education Studies, Faculty of Education, University of the Free State, Bloemfontein, 9300, South Africa

${ }^{6}$ Department of Educational Foundations, Faculty of Education, University of Nigeria, Nsukka

\section{ABSTRACT}

This study was carried out to determine the relationship between socio-psychological factors and students' academic performance in chemistry. Three research questions and three hypotheses were formulated to guide the study. The research design was correctional research design. A questionnaire developed by the researchers was used to collect data. The questionnaire was face validated and trial tested. Internal consistency reliability index of 0.75 was obtained using Cronbach alpha method. Data obtained were analyzed using simple linear regression analysis. The major findings revealed among others that there is a significant relationship between attitude and students' academic performance in chemistry; there is a significant relationship between motivation and students' academic performance in chemistry and that there is a significant relationship between self-regulation and students' performance in chemistry. These findings have implications for students' career choices in science and engineering education in Universities in Nigeria. The significant positive relationship obtained for sociopsychological factors and students' achievement in Chemistry implies an improved enrolment as well as performance of students in science and engineering education at University level.

KEYWORDS: Achievement, Chemistry, Performance, Science and Engineering Education, Socio-Psychological

Received: Jun 08, 2020; Accepted: Jun 28, 2020; Published: Sep 11, 2020; Paper Id.: IJMPERDAUG202021

\section{INTRODUCTION}

Chemistry is one of the fundamental ingredients of technology. Chemistry a central science because its interest lies between those of biology and physics. Peter (2013) stated that chemistry is the study of matter and its transformations and the development of methods to manipulate these transformations to create new and useful forms of matter. Chemistry is the scientific study of the interaction of chemical substances that are constituted of atoms or the subatomic particles: protons, electrons , and neutrons (Adesoji\&Ogini,2012) Chemistry unlike other branches of science, like mathematics, is not compulsory in "O" level but it is taken depending on the specialization of the students in science combination, which can be PCB(Physics, Chemistry and Biology), PCM(Physics, Chemistry and Mathematics), PCG(Physics, Chemistry and Geography) and BCG(Biology, Chemistry and Geography). 
Chemistry as a subject provides broader knowledge about science in general which is compulsory to every individual that aim to study the environment, or climate change related courses. Despite all efforts made to encourage students to study chemistry, there is still poor performance (Njoku,2015). There has been wide cry each year when WAEC or NECO releases their annual results as a result of students' poor performance especially in science subjects (Salami, Mohammed \& Ogunlade, 2012). Candidates' performance at the senior School Certificate Examination (SSCE) conducted by WAEC and NECO has consistently remained poor with Chemistry having one of the worst and poorest results over the years (Ibe \& Madusnum, 2001). Reports show that adequate skills needed in chemistry by students are not developed. Also, analysis of the students' performance in WAEC shows that the raw students' mean scores from 2015-2017 never exceeded 40\% (WAEC Chief Examiner's Report 2013, 2014, 2015, 2016 and, 2017). Yet, chemistry is a prerequisite to all courses in medicine and related field, all engineering courses, pharmacy and many others that are considered prestigious by the society

Academic performance refers to how well a student is accomplishing his or her tasks and studies (Scortt, 2012). According to Ward, Stocker and Murray-Ward (2006) academic performance refers to the outcome of education; the extent to which the students, teachers or institutions have achieved their educational goals. Academic performance is the ability to study and remember facts and being able to communicate one's knowledge verbally or written on paper (Answers, 2010). In the context of this study, academic performance refers to the extent to which students have achieved mastery of the objectives of the subjects they are exposed to in school. Grades are the most well-known indicator of academic performance. Grades are the student's "score" for their classes and overall tenure. Grades are most often a tallying or average of assignment and test scores and may often be affected by many factors.

Factors affecting academic performance in chemistry vary and are unclear Academic performance is affected either by social, psychological, economic, environmental or personal factors. Any of these factors may have a powerful influence on academic performance of students either positively or negatively, but this vary from one society to another. The factors may include negative attitudes of students towards chemistry, methodology used by teachers, students' inability to manage their time, peers influence, family factors and the likes (Oginni, Alaka \& Saibu, 2013; Njoku, 2015; Igboanugu, 2015). According to Adunola (2011), Ganyaupfu (2013), teaching is a collaborative process that involves interaction between students and teachers that at the end brings about change in the students' behavior. Sociopsychological factors in teaching and learning process is a multidimensional concept that measures various interrelated aspects of learning in educational system. Socio-Psychosocial factors like attitude, motivation (consisting of academic discipline, commitment to school and optimism), social control(consisting of family attitude towards education and family involvement, relationship with school personnel), self-regulation (consisting of managing feelings, orderly conduct, and thinking before acting) and social interaction of students are factors which may affect students' academic performance and are essential for the delivery of high quality teaching and learning process Therefore, consistent evaluation of the psychosocial factors is very crucial most especially among secondary school students as that is the foundation for future achievements. In this study, the socio-psychological factors considered are attitude, motivation and self- regulations.

Attitude is important in understanding human behavior. Attitude generally is defined as a complex mental state involving beliefs (Hussain, Ali, Khan, Ramzan \& Qadeer, 2011). It is an individual's prevailing tendency to respond favourably or unfavourably to an object, person or group of people, institutions or events. Within the context of social psychology, attitude is a subjective or mental preparation for action. It defines the outward and visible postures and human 
beliefs. Attitudes determine what each individual will see, hear and do. Attitudes can be positive (values) or negative (prejudice). Attitude is generally defined as an individual's tendency to react positively or negatively towards a stimulus. An attitude is a relatively enduring organization of beliefs, feelings and behavioural tendencies towards socially significant objects, groups, events or symbols (Hogg\&Vaughan,2005). Attitude towards school and learning can be understood as beliefs, thoughts and opinions about school and learning. Attitude towards chemistry denotes interests or feelings towards studying chemistry. It is the students' disposition towards like or 'dislike' of chemistry, it means approach assumed by an individual for solving problems, assessing ideas and making decisions. Students' beliefs and attitudes have the potential to either facilitate or inhibit learning (Olatunde, 2009).

Students also need a reason or motivation to perform well academically an individual that is highly motivated will be more alert and responsive and will put effort into actions. Motivation may also be regarded as a decision-making process, through which the individual chooses the desired outcomes and sets in motion the behavior appropriate to the outcomes (Riley, 2012). Motivation is a psychological process which leads anyone to act in a way that helps him/her to fulfill unsatisfied needs (Latham, 2011).Kostelecky (2005) defined motivation as an internal state or condition that activates guides and maintains or directs behaviour. Motivation is one of the most important factors in universities or educational sector especially when we are talking about the performance of the students in their studies or projects. Student's motivation is one of the important factors that show new ways of learning to students. So many studies have been conducted to predict relationship between student's motivation and its impact on student's academic performance (Eymur, 2011; Febriana, 2017). The student's motivation is divided into two sub types. First one is intrinsic motivation and second one is extrinsic motivation

The term "self-regulation" in this study refers to the degree to which students appropriately regulate and express their feelings and behaviour, as well as how they think about the consequence of behaviour in school contexts. In contrast to social control, self-regulation is more aligned with the concept of personal control, which is "the ability of the individual to refrain from meeting needs in ways which conflict with the norms and rules of the community". People generate thoughts, feelings and actions and adapt those to the attainment of personal goals. Behavioural self-regulation involves self-observing and strategically adjusting performance processes, such as one's method of learning (Beishuizen \& Steffens, 2011). Individuals regulate their own functioning in order to achieve goals or change how they are thinking. The selfregulation of cognition and behaviour are important aspects of learning and the extent to which school students become self-regulators of their own learning influences their academic success (Zimmerman, 2008; Zimmerman \& Schunk, 2011)

According to Ugwuanyi et al. (2020), emotional intelligence, self-esteem, and self-efficacy correlate positively with students' achievement in mathematics. Ndirika \& Agommuoh (2017) found that factors like home, school, and society determine female active participation in science and technology in Nigeria. Gana et al. (2019) found that motivation, selfefficacy, and locus of control are significant corelates of students' achievement in STEM subjects like physics. Bahar and Adiguzel (2016) found that American students' interest in STEM is significantly dependent onself-motivation. Otoo et al. (2018) found that students' confidence and motivation significantly determine their interest in the learning of mathematics. Caspi et al. (2019) revealed that students' interest in STEM courses is determined by their positive attitudes. Ugwuanyi and Okeke (2020) found that students' interest in STEME courses are significantly determined by motivation, self-efficacy, self-esteem, and task persistence. 
Parents, teachers, curriculum experts and evaluators have expressed considerable concern over the deteriorating students' performance because its effects are equally seen on the society in terms of death of manpower in the country. Could the dismal academic performance of chemistry students be traceable to some socio-psychological factors? This study sought to establish whether there is a relationship between socio-psychological factors and academic performance of chemistry students in Enugu state.

\section{PURPOSE OF THE STUDY}

Specifically, the study investigated the relationship between;

- Attitude and students' academic performance in chemistry.

- Motivation and students' academic performance in chemistry.

- Self-regulation and students' academic performance in chemistry.

\section{RESEARCH QUESTIONS}

- What is the relationship between attitude and students' academic performance in chemistry?

- What is the relationship between motivation and students' academic performance in chemistry?

- What is the relationship between self-regulation and students' academic performance in chemistry?

\section{HYPOTHESES}

The following null hypotheses were tested at 0.05 level of significance.

- $\mathbf{H o}_{1}$ : There is no significant relationship between attitude and students' academic performance in chemistry.

- $\mathbf{H o}_{2}$ : There is no significant relationship between motivation and students' academic performance in chemistry.

- $\mathbf{H o}_{3}$ : There is no significant relationship between self-regulation and students' academic performance in chemistry.

\section{METHOD}

This study adopted correlational survey which according Nworgu (2006) is a type of study that seeks to establish what relationship exists between two or more variables. This study established the relationship among variables of attitude, motivation, self-regulation and academic performance of students in chemistry in Nsukka local government area of Enugu state. The area has 31 government secondary schools.

The population consists of 1,062 students offering chemistry in registered government owned secondary schools within Nsukka local government area of Enugu state. The sample size of the study comprised 100 Senior Secondary 2 (SS 2) Chemistry students from five (5) secondary schools that were randomly sampled out of the 31 secondary schools in the area of study. Twenty (20) students were selected from each of the five (5) secondary schools sampled using simple random. In all, 100 students of both genders were used to collect data.The instrument used for data collection was a Questionnaire. The questionnaire was structured on a four point rating scales of Strongly Agree (4), Agree (3), Disagree (2), Strongly Disagree (1) .The reliability of the instrument was established using Cronbach Alpha method which was used 
to determine the internal consistency reliability of the items of the instrument. A reliability index of 0.75 was obtained indicating that the instrument was reliable

Data collected were analyzed using simple linear regression analysis. The correlation coefficient aspect of regression analysis was used to answer the research questions while t-test aspect of regression analysis was used to test the hypotheses at 0.05 level of significance.

\section{RESULTS}

The result of the analysis of data were presented according to the research questions and hypotheses used in the study.

Research Question One: What is the relationship between attitude and students' academic performance in chemistry?

Table 1: Correlational Analysis of the Relationship between Students' Attitude and Academic Performance

\begin{tabular}{|c|c|c|c|c|c|}
\hline Variables & $\mathbf{N}$ & Mean & Standard deviation & Correlation coefficient $(\mathbf{r})$ & Coefficient of determination $\left(\mathbf{r}^{2}\right)$ \\
\hline Performance & \multirow{2}{*}{100} & 13.4 & 2.26 & \multirow{2}{*}{.295} & \multirow{2}{*}{$0.087(8.7 \%)$} \\
\cline { 1 - 3 } Attitude & & 25.5 & 3.8 & & \\
\hline
\end{tabular}

The result in Table 1 above shows the relationship between attitude and academic performance of chemistry students. From the Table, the correlation coefficient (r) between attitude and academic performance of students is 0.295. This result shows a low positive relationship between students' attitude and their performance scores. The coefficient of determination is 0.087 implying that $8.7 \%$ variation in students' performance in Chemistry is attributed to their attitude.

Ho $\mathbf{H}_{1}$ : There is no significant relationship between attitude and chemistry students' academic performance in chemistry.

Table 2: Regression Analysis of the Relationship between Attitude and Chemistry Students' Academic Performance in Chemistry

\begin{tabular}{|c|c|c|c|c|c|c|}
\hline Variable & Beta & $\mathbf{r}$ & $\mathbf{r}^{2}$ & $\mathbf{t}$ & df & Sig. \\
\hline Achievement & \multirow{2}{*}{.295} & .295 & 0.087 & 6.048 & 98 & 0.000 \\
\hline Attitude & & & & & \\
\hline
\end{tabular}

Table 2 shows that the standardized regression coefficient (Beta) for the relationship between attitude and chemistry students' academic performance in chemistry is .295 which is significant at $p=.000$. Therefore, since the $p<.05$, the null hypothesis of no significant relationship between attitude and students' achievement in chemistry was rejected. Thus, there is a significant positive relationship between attitude and students' achievement in chemistry.

Research Question Two: What is the relationship between motivation and students' academic performance in chemistry?

Table 3: Correlational Analysis of the Relationship between Students' Motivation and Academic Performance in Chemistry

\begin{tabular}{|c|c|c|c|c|c|}
\hline Variables & $\mathbf{N}$ & Mean & $\begin{array}{c}\text { Standard } \\
\text { deviation }\end{array}$ & Correlation coefficient $(\mathbf{r})$ & Coefficient of determination $\left(\mathbf{R}^{\mathbf{2}}\right)$ \\
\cline { 1 - 3 } Performance & \multirow{2}{*}{100} & 13.4 & 2.26 & \multirow{2}{*}{.241} & $0.058(5.8 \%)$ \\
\cline { 1 - 3 } Motivation & 25.6 & 3.65 & & .241 \\
\hline
\end{tabular}

Table 3 shows that the correlation between motivation and students' performance scores is 0.241 . This shows a low positive relationship between students' motivation and their performance scores in chemistry with a coefficient of determination of $.058(5.8 \%)$. 
$\mathbf{H o}_{2}$ : There is no significant relationship between motivation and chemistry students' academic performance.

Table 4: Regression Analysis of the Relationship between Motivation and Chemistry Students' Academic Performance

\begin{tabular}{|c|c|c|c|c|c|c|}
\hline Variable & Beta & $\mathbf{R}$ & $\mathbf{R}^{2}$ & $\mathbf{t}$ & $\mathbf{d f}$ & Sig. \\
\hline Performance & \multirow{2}{*}{.241} & .241 & 0.058 & 6.089 & 98 & 0.000 \\
\hline Motivation & & & & & \\
\hline
\end{tabular}

Table 4 shows that the standardized regression coefficient (Beta) for the relationship between motivation and chemistry students' academic performance in chemistry is .241 which is significant at $p=.000$. Therefore, since the $p<.05$, the null hypothesis of no significant relationship between motivation and students' achievement in chemistry was rejected. This implies that there is a significant positive relationship between motivation and students' achievement in chemistry.

Research Question Three: What is the relationship between self-regulation and students' academic performance in chemistry?

Table 5: Correlational Analysis of the Relationship between Self-Regulation and Students' Academic Performance in Chemistry

\begin{tabular}{|c|c|c|c|c|c|}
\hline Variables & $\mathbf{N}$ & Mean & $\begin{array}{l}\text { Standard } \\
\text { deviation }\end{array}$ & $\begin{array}{c}\text { Correlation coefficient } \\
(\mathbf{r})\end{array}$ & $\begin{array}{c}\text { Coefficient of determination } \\
\left(\mathbf{R}^{2}\right)\end{array}$ \\
\hline Performance & \multirow[b]{2}{*}{100} & 13.4 & 2.26 & \multirow[b]{2}{*}{.472 } & \multirow[b]{2}{*}{$0.233(23.3 \%)$} \\
\hline $\begin{array}{c}\text { Self- } \\
\text { regulation }\end{array}$ & & 26.1 & 3.31 & & \\
\hline
\end{tabular}

Table 5 the correlation between self-regulation and students' academic performance scores is 0.472 . This shows a moderate positive relationship between students' self-regulation and their performance scores with a coefficient of determination of $0.233(23.3 \%)$.

Hypothesis three: There is no significant relationship between self-regulation and chemistry students' academic performance.

Table 6: Regression Analysis of the Relationship between Chemistry Students' Performance and their SelfRegulation

\begin{tabular}{|c|c|c|c|c|c|c|}
\hline Variable & Beta & $\mathbf{R}$ & $\mathbf{R}^{2}$ & $\mathbf{t}$ & df & Sig. \\
\hline Performance & \multirow{2}{*}{.472} & .472 & .223 & 3.118 & 98 & 0.002 \\
\hline Self-regulation & \multirow{2}{*}{} & & & & & \\
\hline
\end{tabular}

Table 6 shows that the standardized regression coefficient (Beta) for the relationship between self-regulation and chemistry students' academic performance in chemistry is .472 which is significant at $p=.000$. Therefore, since the $p<.05$, the null hypothesis of no significant relationship between self-regulation and students' achievement in chemistry was rejected. This implies that there is a significant positive relationship between self-regulation and students' achievement in chemistry.

\section{DISCUSSION OF THE FINDINGS}

The main aim of the study was to establish whether there is a relationship between socio-psychological factors and academic performance of chemistry students in secondary schools. The result of the findings showed that there exists a significant positive relationship between chemistry students' attitude and academic performance. This means that students' attitude influences their academic performance. When a student has the right attitude towards chemistry, there is a tendency of he/she doing well in chemistry leading to a good academic performance. The results also showed that there 
exists a significant positive relationship between self-regulation, motivation and chemistry students' academic performance. The finding could be attributed to some factors like putting up and adhering to a timetable for reading, doing assignments and reading ahead before examination. When a student maps out things to do daily and follows them sequentially there is chances of success. This finding is supported by Beishuizen and Steffens (2011) that individuals regulate their own functioning in order to achieve goals or change how they think. These findings are in line with Olatunde (2009) who pointed out that students' beliefs and attitudes have the potential to either facilitate or inhibit learning. This means that those students who do well in a subject generally have more positive attitude towards that subject and those who have more positive attitudes towards a subject tend to perform better in the subject. This finding is supported by Covington (2000) who also found that students with higher motivation are more likely to attain better academic outcomes. Buttressing the above findings are the findings of Bahar and Adiguzel (2016), Ndirika and Agommuoh (2017), Otoo et al. (2018), Caspi et al. (2019), Gana et al. (2019), Ugwuanyi et al. (2020), Ugwuanyi and Okeke (2020).

According to Bahar and Adiguzel (2016) found that American students' interest in STEM is significantly dependent onself-motivation. Ndirika \& Agommuoh (2017) found that factors like home, school, and society determine female active participation in science and technology in Nigeria.Otoo et al. (2018) found that students' confidence and motivation significantly determine their interest in the learning of mathematics. Caspi et al. (2019) revealed that students' interest in STEM courses is determined by their positive attitudes.Gana et al. (2019) found that motivation, self-efficacy, and locus of control are significant corelates of students' achievement in STEM subjects like physics. Ugwuanyi et al. (2020) found that emotional intelligence, self-esteem, and self-efficacy correlate positively with students' achievement in mathematics. Ugwuanyi and Okeke (2020) found that students' interest in STEME courses are significantly determined by motivation, self-efficacy, self-esteem, and task persistence.

\section{CONCLUSIONS}

In view of the findings of this study, it has been clearly determined that chemistry student's attitude, motivation and selfregulation have a lot to do with their performance in chemistry. Considering the role of chemistry in technological development of any nation, there is the need to apply all possible measures to ensure proper teaching and learning of the subject which will make for high academic performance of the students. There is therefore the need to motivate the students as well as encourage them to develop strong self-regulation as well as positive attitude towards chemistry in order to enhance the enrolment of students in science and engineering courses at higher institutions of learning.

\section{IMPLICATIONS AND RECOMMENDATIONS}

- The findings of this study indicate that self-regulation is related to students' academic achievement in chemistry. This implies that students should be encouraged to develop good study habits, be able to manage their emotions and feelings especially when dealing with difficult concepts in chemistry and endeavour to continue on the routine as it could improve students' performance.

- Students should also endeavour to develop the right attitude towards chemistry to enhance their chances of enrolling in science and engineering careers at higher institutions.

- Both parents and teachers should be aware that motivation is related to students' academic achievement in chemistry, thus, they should always strive as much as possible to motivate the students as that will bring about better performance in chemistry. 
- The school should ensure that students are aware of the fact that attitude, motivation and self-regulation jointly relate to their academic performance in chemistry. This can be done by organising public lectures, workshops or seminars to enlighten them.

\section{ACKNOWLEDGMENTS}

The researchers wish to acknowledge all the participants for this study for their cooperation and active participation throughout the conduct of the research. We appreciate Dr. U.H. Onah also for serving as a contact person for any information or clarification regarding the conduct of this research.

\section{REFERENCES}

1. Adesoji, F. A. (2008). Managing students' attitude towards science through problem-solving instructional strategy.Journal of Anthropologist, 10(1), 21-24.

2. Abid Ali, WasfiDhahir, and SamaherSabri Hameed. "A Study on Factors Inducing Stress Among Students in Nursing College." International Journal of Human Resources Management (IJHRM) ISSN (P) (2018): 2319-4936.

3. Adesoji, F.A \&Ogini, A.M. (2012) Students' aptitude indices as predictors of learning outcome in chemistry.British Journal of Art \& Social Sciences, 8(11),174-182.

4. Adunola, O. (2011). An Analysis of the Relationship Between Class Size and Academic Performance of Students, Ego Booster Books, Ogun State, Nigeria.

5. Bahar, A., \& Adiguzel, T. (2016). Analysis of Factors Influencing Interest in STEM Career: Comparison between American and Turkish High School Students with High Ability. Journal of STEM Education - Innovations and Research, 17(3), 64-69.

6. Beishuizen, J., \& Steffens, K. (2011).A conceptual framework for research on self-regulated learning. In R. Carneiro, P. Lefrere, K. Steffens, K. \& J. Underwood (Eds.), Self- $\quad$ regulated Learning in Technology Enhanced Learning Environments: A European Perspective Sense Publishers.

7. Caspi, A., Gorsky, P., Nitzani-Hendel, R., Zacharia, Z., Rosenfeld, S., Berman, S., \& Shildhouse, B. (2019). Ninth-grade students' perceptions of the factors that led them to major in high school science, technology, engineering, and mathematics disciplines. Science Education, 103(5), 1176-1205. https://doi.org/10.1002/sce.21524

8. Covington, M. V. (2000). Goal theory, motivation, and school achievement: An integrative review. Annual Review of Psychology, 51, 171-200. doi:10.1146/annurev.psych.51.1.171.

9. Eymur,G. (2011) An Investigation of the Relationship Between Motivation and Academic Achievement of Pre- service Chemistry Teachers. Education and science https://www.researchgate.com

10. Fabriana,B (2017)Analysis of students 'achievement motivational in learning chemistry International journal of Science \& Applied science: Conference Series https://www.researchgate.com

11. Gana, C.S.,Ugwuanyi, C.S., \& Ageda, T.A. (2019). Students' psychological predictors of academic achievement in physics. International Journal of Research and Innovation in Social Science (IJRISS), III (IX), 23-28. https://www.rsisinternational.org/journals/ijriss/Digital-Library/volume-3-issue-9/23-28.pdf

12. Ganyaupfu, E.M. (2013). Factors Influencing Academic Achievement in Quantitative Courses among Business Students of Private Higher Education Institutions, Journal of Education and Practice, 4(15):57-65.

13. Hasan, Haslinda, Amran Harun, and MohdShaffran Zainal Rashid. "Factors influencing online purchase intention in online brand." International Journal of Business Management \& Research 5.5 (2015): 63-72. 
14. Hogg, M., \& Vaughan, G. (2005).Social Psychology (4th edition). London: Prentice-Hall

15. Hussain, S., Ali, R., Khan, M.,Ramzan, M.,\&Qadeer, Z. (2011).Attitude of secondary school teachers towards teaching profession.International Journal of Academic Research.

16. Humra, Y. A. S. H. B. A. "Behavioral finance: An introduction to the principles governing investor behavior in stock markets." International Journal of Financial Management 5.2 (2014): 23-30.

17. Indahwati, Nanik, and KolektusRistanto. "The application of pettlep imagery exercise to competitive anxiety and concentration in Surabaya archery athletes." International Journal of Educational Science and Research (IJESR) 6.3 (2016).

18. Ibe, A. \& Maduabam, C. (2001). Why students fail examinations, Journal of Applied Psychology 1, 55-62.

19. Igboanugo,B.I.(2015). Effects of peer teaching on students' achievement and interest in senior secondary school difficult chemistry concepts. International journal of Educational Research, 12(2),61-71.

20. Latham, G. (2011).Work Motivation: History, Theory, Research and Practice. NJ, SAGE.

21. Ndirika, M. C., \& Agommuoh, P.C. (2017). Investigating Factors Influencing Girls Participation in Science and Technology Education in Nigeria. IOSR Journal of Research \& Method in Education (IOSRJRME), 07(03), 50-54. https://doi.org/10.9790/7388-0703035054

22. Nworgu, B. G. (2006). Educational research, basic issues and methodology. By University Trust Publishers Nsukka Enugu.

23. Ogini, A.M.\& Alaka, M.O. (2013) School factors as correlates of students' achievement in chemistry International Journal of Cross Disciplinary(IJCDSE), 3(3).https://Infonomics.society.org

24. Oginni, A. M., Awobodu, V. Y., Alaka, M. O., \& Saibu, S. O. (2013). School factors as correlates of students' achievement in Chemistry. International Journal for Cross-Disciplinary Subjects in Education, 3(3), 1516-1523.

25. Olatunde, Y.P. (2009). Students attitude towards Mathematics and academic achievement in some selected secondary schools in Southwestern Nigeria. European Journal of Scientific Research, 36: 336-341

26. Otoo, D., Iddrisu, W. A., Kessie, J. A., \& Larbi, E. (2018). Structural Model of Students' Interest and Self-Motivation to Learning Mathematics. Education Research International, 2018. https://doi.org/10.1155/2018/9417109

27. Peter, S.E (2013). What is chemistry? Retrieved on 14th July, 2020 from https://www.peteralkins.com/university press/978-019-968398-7.

28. Salman, M.F., Mohammed, A.S., Ogunlade, A.A. \&Ayinla, J.O. (2012). Causes of mass failure in senior school certificate mathematics examinations as viewed by secondary school teachers and students in Ondo, Nigeria. Journal of Education and Practice, 3(8), 79-88.

29. Scott, D. (2012). http://www.ehow.com/about_6398585_meaning-academic..

30. Ugwuanyi, C. S., \& Okeke, C. I. O. (2020). Determinants of university students' interest in science, technology, engineering and mathematics education in nigeria: a case of a structural equation modeling. International Journal of Mechanical and Production Engineering Research and Development, 10(3): 6209-6218. http://dx.doi.org/10.24247/ijmperdjun2020590

31. Ugwuanyi, C. S., Okeke, C.I.O. \& Asomugha, C.G., (2020).Prediction of learners' mathematics performance by their emotional intelligence, self-esteem, and self-efficacy.Cypriot Journal of Educational Science.15(3), 492-501. http://dx.doi.org/10.18844/cjes.v\%vi\%i.4916

32. Ward, A., Stocker, H.W.,\& Murray-ward, M.C. (2006). Achievement and ability tests definition of the domain. Retrieved, June 7, 2011, from http://www.en.wikipedia.org/wiki/academic. 
33. West African Examination Council (WAEC) 2013, 2014, 2015, 2016, 2017 and 2018. Chief Examiners reports for may/June Senior Certificate Examination: Yaba, lagos: amao press ltd.

34. Zimmerman, B. J. (2008). Investigating self-regulation and motivation: Historical background, methodological developments, and future prospects. American Educational Research Journal, 45(1), 166-183. doi:10.3102/0002831207312909.

35. Zimmerman, B. J., \&Schunk, D. H. (2011).Self-regulated learning and performance. In B. J. Zimmerman and D. H. Schunk (Eds.), Handbook of self-regulation of learning and performance (pp. 1-12). New York: Routledge. 